\title{
Perceptions Concerning Obstacles, Stereotypes and Discrimination Faced by Female Sports Reporters and Other Female Sports Professionals
}

\author{
By Tess Hyre* \\ Steve Chen ${ }^{\dagger}$ \\ Monica Larson ${ }^{+}$
}

\begin{abstract}
Female athletes and sports professionals (i.e., coaches and broadcasters) are often victims of stereotyping in the sports industry. Despite the enactment of Title IX, concerns over inequality in lack of airtime for women sports, excessive sexism, discrimination, and disrespect toward female athletes and sports professionals continues to rise. This study contained two components that addressed perceived obstacles, stereotypes and discrimination faced by female sports reporters and various trends of studies related to gender inequality. The results of the metaanalysis indicated that inappropriate representation of female professionals' and athletes' image and persona is the most relevant and emergent issue today. The perceptions of 157 survey respondents from a university in the Appalachian Region supported the findings of past studies, which indicated stereotypical portrayals of female reporters. Respondents also showed their preferences toward men's sports, and had more respect and faith in male sports journalists. Recommendations (i.e., using education as a means to counter negative stereotypes) and suggestions are given to raise the awareness for gender inequality and empower future female sports reporters.
\end{abstract}

Keywords: Female sports reporters, female athletes, gender inequality, stereotypes, discrimination

\section{Introduction}

FOX Broadcasting's series, "Pitch" (2016), depicts a dramatic story about fictional character Ginny Baker as the first African-American female pitcher in Major League Baseball. Although the portrayal of a female athlete playing in one of the most dominant professional sports in the United States is a celebratory event, the TV series reveals how such a ground-breaking feminist achievement could be tainted by media biases and social prejudices. The show exposes widely held notions that female athletes cannot be capable or talented enough to compete with their male counterparts.

When people initially think of sports, they think of men competing in games against other men. Seldom does it occur to them that women can be interested in playing sports against other women, and it certainly never crosses their minds that women would compete against men. Sports are perceived as

\footnotetext{
* Graduate, Shepherd University, Shepherd University, USA.

$\uparrow$ Professor of Sport Management, College of Business and Technology, Morehead State University, USA.

${ }^{+}$Associate Professor of Communication, Shepherd University, USA.
} 
activities, professions, and cultural phenomena dominated, controlled, and operated by men.

A history of formal sports can be traced back to when the Greeks created the Olympics in 776 B.C. to honor the god, Zeus (Woods, 2011). Due to the conversion to Christianity in the Roman Empire, the Olympic games ceased to be held for more than a thousand years and did not return until 1896, when they reappeared with more sports and additional interest from athletes and viewers than ever before (Leeds and Von Allmen, 2014; Woods, 2011). However, the inventor of the modern Olympic Games, Pierre de Coubertin, never intended to create a competition that included female participation.

Modern women's sports began to emerge around the World War II era and gained notice in the 1960s (Sage and Eitzen, 2013). In 1972, President Nixon signed into law Title IX of the Educational Amendment. The law mandates that any educational program receiving federal assistance can lose its funding if it discriminates on the basis of sex of people and participants (Daulton, 2013). The enactment of Title IX helped remove many barriers to sports participation that women faced; however, it did not necessarily guarantee or promote the recognition of women's athletic ability, achievement, and sport competency from public's and media's view (Jacobs and Schain, 2009).

There are numerous challenges, obstacles, and discriminations that female sports professionals (such as professional athletes, athletic administrators, and sports journalist/reporters, etc.) encounter. Examples of these problems may include: receiving unequal payment for the same amount of effort and work, receiving less media attention and television coverage, being the subject of inappropriate media portrayals(often with sexual objectification), being restricted from locker room access for conducting interviews, and experiencing a lack of respect from general public and male peers for their professional skills and knowledge (Arnold, Chen, and Hey, 2015; Carlson, 2010, Clifton, 2012; Lamoureux, 2012; Rand, 2008; Torres, 2016; Women's Sports Foundation, 2015). In the following Review of Literature, the authors discuss these aforementioned problems with more examples and details.

\section{Review of Literature}

\section{Gender Biases of Media Representation and Issues of Media Coverage}

In 1999, the Women's World Cup had more than 658,000 fans in the stands and one billion television viewers worldwide (Shipley, 1999). Since then, the U.S. Women's Soccer team has been a perennial power, winning numerous championships in major international events. However, they struggle to receive the deserved respect for their athletic success (Jacobs and Schain, 2009; Tanner, 2001; Torres, 2016). To this day, their outstanding achievement and dominance in women's soccer receives limited media attention and coverage when compared to any other men's major sports (Harwell, 2014; Lapiano, 2008). 
The total media coverage time between male and female sports varies widely. ESPN is one of the largest television networks to feature both men's and women's sports. Its most popular daily program, Sports Center, dedicated only $2 \%$ of airtime to women's sports in 2014 (Kroh, 2015). Its affiliated station in the Los Angeles area had only $1.5 \%$ of national and local airtime covering exclusively women's sports (Harwell, 2014). In fact, the percentage of female sports coverage time on television has stagnated since 1999. Additionally, more than $40 \%$ of collegiate athletes are women, and yet those women receive a meager $4 \%$ of college media coverage (Ewinegar, 2013).

Low revenues coming from broadcasting rights and the lesser popularity of women's sports can both be attributed to the lack of women's sports coverage. Without adequate TV coverage and broadcasting incomes, it is impossible to narrow the salary gap between the men and women athletes. Female athletes also lose sponsorship opportunities due to lack of media exposure (Harwell, 2014).

On top of the minuscule amount of coverage time for women's sports, there are other negative issues associated with the actual content and image representations. Sport media's depictions of female athletes and journalists are filled with stereotypes and biases. Female athletes are either criticized as being too masculine or not athletic enough (Ezzell, 2009). The media often fixates on female athletes' and sports professionals' appearance and outfits, instead of focusing on their performance. Many people believe that women's athletics would not be marketable without a certain amount of sex appeal. Female sports reporters are often treated as beautiful objects that are employed to arouse visual sensation, rather than considered as intelligent, professional commentators.

\section{Discrimination and Prejudice in Work Settings and on the Field}

To be powerful athletes and succeed in the sports world, women must embrace attributes usually considered as masculine, while simultaneously maintaining their feminine identities. In doing so, many female athletes perceive themselves as being different from other "ordinary" females who do not partake in sports. The pressure that is placed on female athletes to uphold a certain persona continues to rise (Mean and Kassing, 2008). Unfortunately, regardless of their high level of athleticism, competitiveness, and mental toughness, female athletes are not viewed as equal to male athletes. Furthermore, the price of being mentally and physically strong has caused female athletes to be labeled as butch, not feminine, or lesbians (Ezzell, 2009). Most of these perceptions are just myths and untested stereotypes.

Nowadays, the pay between men and women athletes and professionals is far from equal. Female tennis players are considered lucky to make half as much as male tennis players (Lopiano, 2008). A collegiate head coach of a women's NCAA D1 team makes on average less than $50 \%$ of male head coaches' earnings (Women's Sports Foundation, 2015). The earnings of female professional athletes are significantly less because their leagues often cannot secure lucrative TV broadcasting rights and sponsorship deals. 
In addition to the salary gap between the two genders of athletes and professionals, female sports reporters/journalists specifically often experience unfair treatment and discrimination in an unfriendly male-dominated work environment. During the 1977 Major League Baseball World Series, the reporter, Melissa Ludtke, was prohibited from entering the locker room for interviews. This incident led to a lawsuit that granted all reporters (male or female) the right to enter the locker room after post games (Carlson, 2010). Despite this case decision, female reporters have still been harassed or verbally abused in the football locker room (Carlson, 2010). Demeaning comments and misogynistic jokes create a hostile work environment, even if the words or actions may not be directed to a specific female reporter (Carlson, 2010).

Although having an attractive appearance seems to be a requirement for women to land a sports media job, the same quality often works against women once employed. Erin Andrews is one of the most well-known female sports reporters who has been discriminated against because of her good looks. Prior to a Cubs-Brewers game in August 2008, Mike Nadal of Gate House News Service judged Andrews on how she carried herself, and insinuated that she was flirting with the players rather than doing her job (Rand, 2008). In general, male athletes and reporters garner viewers due to their performance and knowledge, but female athletes and reporters are often judged solely by their appearance. Men carry the torch and earn the spotlight for their athleticism, while women continue to fight to be considered knowledgeable professionals.

In general, sports journalists believe that it is their responsibility to give the audience what it wants, and not build audiences. However, this false logic lets sports media off the hook for the lack of female sports coverage (Kroh, 2015). The reality is that over $95 \%$ of journalists who cover sports are male (Kroh, 2015). That percentage leaves a small window for women to cover female sports. Although the growth of female sports journalists has risen by $21.4 \%$ since 2014, females are still severely underrepresented in the industry (Clifton, 2012; Women's Media Center, 2014). Currently, nearly 10\% of all women reporters are now sports journalists (Women's Media Center, 2014). That statistic translates into approximately five hundred females in sports radio and television, according to a report of University of Toledo Digital Repository (Clifton, 2012). There is room for improvement in hiring more female sports reporters/journalists. However, Kroh (2015) has revealed that female journalists may not always feel comfortable in the work setting. Nor will theybe able to receive the same salary as their male counterparts. Female journalists still feel that they are underappreciated and taken for granted (Clifton, 2012).

\section{Purpose of the Study and Research Questions}

Female sports professionals (athletes, coaches, and journalists) are often trivialized when it comes to earning respect, pay equality, and recognition for their hard work and achievements in the industry. The purpose of this study is to increase awareness of the existing inequalities in the sports world with the goal of promoting changes on prejudicial and discriminatory issues. The 
authors attempt to open readers' horizons by examining social stereotypes, discrimination, and misconceptions that are unfavorably faced by the female sports professionals (particularly sports reporters/journalists). To achieve the purpose of this study, the authors examined the following research questions:

(1) What are the major gender inequality concerns that are associated with female sports and female sports professionals that were examined by scholars?

(2) How do participants perceive female sports in terms of gender equality measures (i.e., understanding of Title IX legislation), popularity and spectatorship interest?

(3) How do participants perceive the trustworthiness, professionalism, and knowledge of female sports reporters/journalists?

It is our hope that the findings of the study will provide more insight to help educate the public and eliminate prejudicial issues and problems.

\section{Methodology}

This section outlines the specific procedures used to examine the perceived stereotypes and opinions toward the female sports professionals and sports journalists (broadcasters) who work in a male-dominated sports industry. The study involves two components: (1) a meta-analysis of prior studies related to stereotypes and discrimination faced by the female athletes; (2) college students' perceptions of female sports journalists' ability, professionalism, and knowledge. Detailed information included is the study design (i.e., number of participants and selected studies for analyses), procedure, and specific instruments for data collection, and the data analysis strategies.

\section{The First Component}

A meta-analysis was conducted to identify the obstacles and challenges that female sports professionals (including athletes, administrators, and journalists) have faced in a male dominated sports world. The examination of past data specifically focused on themes related to female athletes' performance, women sports' popularity, and general public's perceptions and treatment toward the female sports professionals.

\section{Procedure and Analysis}

To respond to the first research question on how the general public perceives female athletes and sports professionals, the researchers collected several peer-reviewed scholarly articles concerning this topic that were published in the last eight years (2008-2016), and conducted a content analysis on those articles. Those articles were chosen from two specific academic 
search engines, Google Scholar and EbscoHost Academic Search Premiere by using key words such as "women's sports," "stereotypes," "discrimination," and "inequality." Eleven articles that fit the aforementioned descriptions were selected for the content analysis. The authors reviewed those 11 articles along with other previous literature that focused on the stereotypical or discriminatory issues concerning female athletes and sports professionals. Five consensus themes were developed after the reviews and discussions. They are: (1) issues related to participation and opportunities, (2) popularity of female sports, (3) image and media representation of female professionals and athletes, (4) workrelated problems faced by the female professional and athletes, and (5) psychosocial prejudice. Theme 1 focused on topics such as growth of female sports participation, increase of female sports professionals in the industries, and other equality concerns and equal accommodations that are highlighted in Title IX opportunities (i.e., equipment, scholarship, travel arrangement, locker rooms, and living condition, etc.) in institutional environments. Theme 2 is related to the popularity of female sports among today's mass-media, which emphasized overall game attendance, spectatorship interest, TV ratings, and hours of coverage of sports programs. Theme 3 addresses how media portray or present female athletes and sports professionals in front of a screen and other media platforms. The common disputes are often associated with sex appeal, objectification of females, and excessive emphasis in feminism. Theme 4 depicted concerns and problems experienced by female sports professionals in the industries. Common discussions revolve around equal opportunities for advancement, equal payment, harassment, and unequal accommodation for performing the jobs (i.e., female reporters were denied male locker room access to conduct interviews). Theme 5 specified numerous types of psychosocial prejudice experienced by the female athletes and sports professionals. Examples of cases included: female athletes are viewed as lesbians, weak, excessively masculine, and less athletic; women's games are not exciting or important; female professionals' male colleagues often undermine female workers' ability and professionalism; and did not give deserved respect to women in the workplace.

The authors would further classify the reviewed articles according to the essence of each theme. A mark was given to an article's content that was considered to be relevant to one or multiple of the five identified themes. Then the authors tabulated the total received " $X$ " within each theme (see details in Figure 1). The final results presented the most commonly addressed themes within the last years among those reviewed articles.

\section{The Second Component}

\section{Participants and Procedure}

In order to examine the adult population's perceptions of female sports journalists' ability, professionalism, and knowledge, this study invited 
undergraduate students of a public university located in the Appalachian Region to participate in a survey. Participants were asked to respond to a series of questions and rate numerous statements concerning perceived competencies and professionalism of female sports journalists. The survey was made available online in Survey Monkey in mid-October of 2016. With the support of the university's athletic department and the Office of Student Affairs, the authors sent an invitational message to the entire campus student body via the institution's central email system. The message was sent out once a week for two continuous weeks. The data collection process closed in mid-November of 2016. The target goal was to reach a minimum of two hundred respondents, approximately $6 \%$ of the total student population. There were 206 students who took the survey; however, only 157 participants' responses were complete and valid for the data analysis. All participants were aged 18 years or older.

\section{Instrumentation}

The survey instrument of perceptions on female sports journalists was created based on research by Carlson (2010), Clifton (2012), and Arnold et al. (2015). Overall, a total of 78 question-items covered the following seven key sections: (1) participants' general perceptions on specific male and female sports reporters' characteristics, professional knowledge, appearance, and credibility (17 items in Table 1), (2) participants' spectator behavior in attending sports games onsite or watching them online (20 items; the results can be found in Table 2), (3) descriptions associated with the female sports reporters (13 items in Table 3), (4) perceptions on issues related to both male and female sports reporters (eight items in Table 4), (5) a comparison of perceived trustworthiness of male and female reporters (18 items in Table 5), (6) rating the level of femininity of a female reporter (one item), and (7) participants' age (one item).

In Section 1 and 5, participants used a five-point Likert Scale to rate their agreement on both male and female sports reporters' specific characteristics, professional knowledge, appearance, credibility, and level of trustworthiness. A rating of 1 indicated "strongly disagree" to the statement and a rating of 5 signified "strongly agree."A high value of Cronbach's alpha value (.851) was obtained for all Likert Scale rating items, which indicate a strong internal reliability existed among the responses $(>.700)$. Participants voted either "yes" or "no" on various issues concerning both male and female sports reporters in Section 4. Those issues dealt with topics such as workplace discrimination, fair treatment, locker room access for interviews, and commentary opportunities for football games. Readers can refer to Table 1 to 5 in the results for more details of question items within each survey section.

\section{Data Analysis}

The authors performed descriptive analyses to explore participants' general perceptions on sports reporters' characteristics, professional knowledge, 
appearance, credibility, and competencies. In addition, participants' interest in attending or watching certain sports games and their word choices associated with the female sports reporters were shown in frequency and percentage. A series of dependent t-tests were performed to verify the differences in participants' perceptions on reporters of both gender concerning the workrelated issues that they havefaced by the reporters and their trustworthiness and professionalism.

\section{Results}

This study intended to highlight the struggles that female sports professionals and athletes have faced both on and off the field. Based on the summary of our meta-analysis in the first component, female athletes and sports professional (including journalists) had faced all types of stereotyping and discriminatory issues, such as sex appeal, inappropriate portrayal of image, lack of professional knowledge, inappropriate emotional and physical treatment, and Title IX violations that were identified by numerous studies (see Figure 1 for detailed information). According to our findings, inappropriate representation of female professionals' and athletes' image and persona is the most relevant and emergent issues with nine of 11 articles (82\%) examining this issue. Fewer studies dealt with the issues associated with work-related problems faced by the female professional and athletes (Theme 4) and popularity of women's sports (Theme 2). Only two (18\%) and three (27\%) of the eleven articles addressed each of the two issues, respectively. 
Figure 1. Summary of Meta-analysis

\begin{tabular}{|c|c|c|c|c|c|}
\hline $\begin{array}{l}\text { Study and Main } \\
\text { Objective }\end{array}$ & $\begin{array}{c}\text { Participation } \\
\& \\
\text { Opportunities }\end{array}$ & Popularity & $\begin{array}{l}\text { Media image } \\
\text { representation }\end{array}$ & $\begin{array}{l}\text { Work- } \\
\text { related } \\
\text { problems }\end{array}$ & $\begin{array}{l}\text { Psycho- } \\
\text { social } \\
\text { prejudice }\end{array}$ \\
\hline $\begin{array}{l}\text { Clifton (2012): The } \\
\text { study reported the } \\
\text { growth of female } \\
\text { sportcasters and their } \\
\text { struggles in fighting } \\
\text { gender inequalities. }\end{array}$ & $\mathrm{X}$ & & $X$ & $\mathrm{X}$ & \\
\hline $\begin{array}{l}\text { Ezzell (2009): The study } \\
\text { examined how people } \\
\text { would label female } \\
\text { rugby athletes' identity } \\
\text { and appearance. }\end{array}$ & & & & & $X$ \\
\hline $\begin{array}{l}\text { Fink (2015): This review } \\
\text { documented the growth } \\
\text { of female sports } \\
\text { participation and } \\
\text { discusses the negative } \\
\text { impact of media } \\
\text { coverage on consumers } \\
\text { and athletes. }\end{array}$ & $X$ & & $\mathrm{X}$ & & $X$ \\
\hline $\begin{array}{l}\text { Khomutova } \\
\text { andChannon, (2015): } \\
\text { This paper explores the } \\
\text { representation of female } \\
\text { athletes within the } \\
\text { Legends Football } \\
\text { League. }\end{array}$ & & & $\mathrm{X}$ & & \\
\hline $\begin{array}{l}\text { Kian et al. (2009): This } \\
\text { study identified gender- } \\
\text { specific descriptors } \\
\text { regularly found in } \\
\text { television and } \\
\text { newspaper sports } \\
\text { coverage. }\end{array}$ & & & $\mathrm{X}$ & & $X$ \\
\hline $\begin{array}{l}\text { Mean \& Kassing (2008): } \\
\text { This study reported } \\
\text { female athletes' } \\
\text { perception of their } \\
\text { image, and sexual and } \\
\text { athletic identity. }\end{array}$ & & & $\mathrm{X}$ & & $X$ \\
\hline $\begin{array}{l}\text { Mutz and Meier (2014): } \\
\text { This study examined the } \\
\text { public attention directed } \\
\text { at individual male and } \\
\text { female players' athletic } \\
\text { performance and } \\
\text { physical attractiveness. }\end{array}$ & & $\mathrm{X}$ & $\mathrm{X}$ & & \\
\hline
\end{tabular}




\begin{tabular}{|c|c|c|c|c|c|}
\hline $\begin{array}{l}\text { Rayburn et al. } \\
\text { (2015):This study } \\
\text { examined female } \\
\text { collegiate athletes' } \\
\text { perception of Title IX } \\
\text { and various gender } \\
\text { stereotypes related to } \\
\text { their athletic experience }\end{array}$ & $\mathrm{X}$ & $X$ & & & $\mathrm{X}$ \\
\hline $\begin{array}{l}\text { Senne (2016): This } \\
\text { study examined various } \\
\text { issues related to gender } \\
\text { equity and female } \\
\text { participation on the field } \\
\text { and in work setting } \\
\end{array}$ & $X$ & & $\mathrm{X}$ & $X$ & \\
\hline $\begin{array}{l}\text { Sherry et al. (2016): The } \\
\text { study addressed the } \\
\text { underrepresentation and } \\
\text { image representation of } \\
\text { female athletes across all } \\
\text { the Australian print } \\
\text { media. }\end{array}$ & $\mathrm{X}$ & $X$ & $X$ & & \\
\hline $\begin{array}{l}\text { Smith (2015): The } \\
\text { findings suggested less } \\
\text { self-objectification } \\
\text { occurs when images of } \\
\text { athletes' performance } \\
\text { are viewed. }\end{array}$ & & & $\mathrm{X}$ & & \\
\hline
\end{tabular}

" $\mathrm{X}$ " indicates the specific addressed theme is presented in the article.

The second component of this study particularly examined work-related stereotypes or discrimination encountered by the female sports reporters/ journalists. The majority of findings are summarized and displayed in Table 1 to 5. According to Table 1, participants, in general, still perceive male reporters more knowledgeable than their female colleagues, particularly if the males are former athletes. There were two separate sets of items scored that showed this phenomenon (statement 7 vs. statement 3: 4.00 vs. 3.71; statement 11 vs. statement 10: 3.21 vs. 3.02). Participants also spend more attention on female reporter's attractiveness (Statement 1). Although a female reporter's attractiveness may not impact the level of her perceived trustworthiness (based on the mean scores of Statements 16 and 17), participants seem to be tolerant of female reporters when a mistake happens on the female's part (Statement 12). This means they are more critical when male reporters make mistakes (Statement 13). 
Table 1. General Perceptions (overall Cronbach Alpha $=.473$ ) 5-point Likert scale $(1=$ strongly disagree, $5=$ strongly agree $)$

\begin{tabular}{|l|c|c|}
\hline \multicolumn{1}{|c|}{ Statements } & Mean & SD \\
\hline 1. I pay attention to female sports reporters' attractiveness. & 3.04 & 1.13 \\
\hline $\begin{array}{l}\text { 2. I pay attention to female sports reporters if they are former } \\
\text { athletes. }\end{array}$ & 3.53 & .94 \\
\hline $\begin{array}{l}\text { 3. I pay attention to female sports reporters because they are } \\
\text { knowledge able of sports. }\end{array}$ & 3.71 & .97 \\
\hline 4. I do not pay attention to female sports reporters. & 2.32 & 1.05 \\
\hline 5. I pay attention to male sports reporters' attractiveness. & 2.89 & 1.28 \\
\hline $\begin{array}{l}\text { 6. I pay attention to male sports reporters if they are former } \\
\text { athletes. }\end{array}$ & 3.85 & 1.01 \\
\hline $\begin{array}{l}\text { 7. I pay attention to male sports reporters because they are } \\
\text { knowledge able about sports. }\end{array}$ & 4.00 & .87 \\
\hline 8. I do not pay attention to male sports reporters. & 2.27 & 1.01 \\
\hline 9. I am knowledgeable on Title IX. & 2.77 & 1.21 \\
\hline 10. Female sports reporters are knowledgeable. & 3.02 & .60 \\
\hline 11. Male sports reporters are knowledgeable. & 3.21 & .59 \\
\hline $\begin{array}{l}\text { 12. I doubt a female sports reporter's credibility when a mistake } \\
\text { happens. }\end{array}$ & 2.90 & 1.05 \\
\hline $\begin{array}{l}\text { 13. I doubt a male sports reporter's credibility when a mistake } \\
\text { happens. }\end{array}$ & 2.99 & 1.01 \\
\hline $\begin{array}{l}\text { 14. When a male sports reporter is less attractive, he is more } \\
\text { credible. }\end{array}$ & 2.08 & .84 \\
\hline $\begin{array}{l}\text { 15. When a male sports reporter is more attractive, he is less } \\
\text { credible. }\end{array}$ & 2.04 & .74 \\
\hline $\begin{array}{l}\text { 16. When a female sports reporter is less attractive, she is more } \\
\text { credible. }\end{array}$ & 2.13 & .90 \\
\hline $\begin{array}{l}\text { 17. When a female sports reporter is more attractive, she is less } \\
\text { credible. }\end{array}$ & 2.07 & .82 \\
\hline
\end{tabular}

Table 2 illustrates the participants' interest in sports spectatorship. It is obvious that participants favor the traditional male big-three sports (football, baseball and basketball). Overall the female sports receive a lower level of preference. The most popular female sport according to attendance and viewership is soccer, which only accounts for $22.8 \%$ of votes. Nevertheless, for those less or non-revenue generating collegiate sports (i.e., soccer and tennis), female teams seem to gain equal level of popularity as the male teams.

Table 2. Spectatorship behavior (number and percentage)

\begin{tabular}{|l|c|c|}
\hline Sports & Attending Games Onsite & Watching on TV or Online \\
\hline Women's Soccer & $36(22.8 \%)$ & $28(17.7 \%)$ \\
\hline Men's Soccer & $33(20.9 \%)$ & $39(24.7 \%)$ \\
\hline Women's Tennis & $17(10.8 \%)$ & $19(12.0 \%)$ \\
\hline Men's Tennis & $13(8.2 \%)$ & $19(12.0 \%)$ \\
\hline Women's Basketball & $26(16.5 \%)$ & $22(13.9 \%)$ \\
\hline Men's Basketball & $72(45.6 \%)$ & $66(41.8 \%)$ \\
\hline Football & $116(73.4 \%)$ & $121(76.6 \%)$ \\
\hline Baseball & $77(48.7 \%)$ & $66(41.8 \%)$ \\
\hline Softball & $24(15.2 \%)$ & $12(7.6 \%)$ \\
\hline I don't watch at all & $23(14.6 \%)$ & $21(13.3 \%)$ \\
\hline
\end{tabular}


The majority of participants would consider female sports reporters or journalists professional $(88.0 \%)$, informative $(68.4 \%)$, and friendly $(60.8 \%)$. They also think the female reporters are considered to be feminine in general (69.3 on a 100-point scale). Only a slim percentage of people would associate female sports reporters or journalists with negative terms, such as mouthy, pushy, unprofessional, dumb, and ignorant (all below 3\%). Nearly 89\% of the participants agreed that a female sports analyst was good enough to work alongside male sports analysts during football coverage. Nevertheless, a high amount of participants thought that female reporters were likely to face discrimination based on their appearance $(75.3 \%)$. More than half of the participants did not think female reporters were treated fairly by their male colleagues.

Table 3. Descriptions Associated with Female Sports Journalists/Reporters

\begin{tabular}{|l|c|c|}
\hline Rank & Description & Total and \% of Votes \\
\hline 1 & Professional & $139(88.0 \%)$ \\
\hline 2 & Informative & $108(68.4 \%)$ \\
\hline 3 & Friendly & $96(60.8 \%)$ \\
\hline 4 & Good looking & $65(41.1 \%)$ \\
\hline 5 & Sweet & $23(14.6 \%)$ \\
\hline 6 & Stern & $19(12.0 \%)$ \\
\hline 7 & Sensitive & $9(5.7 \%)$ \\
\hline T-8 & Whiny & $4(2.5 \%)$ \\
\hline T-8 -8 & Mouthy & $4(2.5 \%)$ \\
\hline T-11 & Pushy & $4(2.5 \%)$ \\
\hline T-11 & Unprofessional & $2(1.3 \%)$ \\
\hline T-11 & Dumb & $2(1.3 \%)$ \\
\hline
\end{tabular}

Table 4. Perceptions on Issues Related to both Male and Female Sports Reporters

\begin{tabular}{|c|c|c|c|}
\hline Case & Condition & Yes & No \\
\hline \multirow[t]{2}{*}{1} & $\begin{array}{l}\text { Female reporters are discriminated against based on their } \\
\text { looks }\end{array}$ & $75.3 \%$ & $6.3 \%$ \\
\hline & Male reporters are discriminated against based on their looks & $22.2 \%$ & $39.5 \%$ \\
\hline \multirow[t]{2}{*}{2} & Female reporters treated fairly by their male counterparts & $20.3 \%$ & $54.4 \%$ \\
\hline & Male reporters treated fairly by their female counterparts & $60.8 \%$ & $9.5 \%$ \\
\hline \multirow[t]{2}{*}{3} & $\begin{array}{l}\text { Female reporters be allowed into men's locker rooms to } \\
\text { conduct interviews }\end{array}$ & $33.5 \%$ & $54.4 \%$ \\
\hline & $\begin{array}{l}\text { Male reporters be allowed into women's locker rooms to } \\
\text { conduct interviews }\end{array}$ & $27.2 \%$ & $60.1 \%$ \\
\hline \multirow[t]{2}{*}{4} & $\begin{array}{l}\text { I accept a female sports analyst's input alongside a table of } \\
\text { male sports analysts during football coverage }\end{array}$ & $88.6 \%$ & $10.1 \%$ \\
\hline & $\begin{array}{l}\text { I accept a female sports analyst's input alongside a table of } \\
\text { male sports analysts during women's basketball coverage }\end{array}$ & $95.6 \%$ & $3.8 \%$ \\
\hline
\end{tabular}

Despite the participants having a positive perception of female reporters' ability and professionalism (as revealed in Table 3 and 4), they still thought female reporters could only be trusted in reporting women's sports (i.e., 
softball, women's soccer, women's basketball and women's tennis). There are significant differences between the level of perceived trustworthiness with male and female reporters in all listed sports $(p<.01 ; \mathrm{t}>2.605)$. Participants are more likely to trust the male reporters on traditional male-dominated sports such as football, baseball, and basketball. Female reporters were considered to be more trustworthy in reporting their own female sports.

Table 5. A Comparison of perceived Trustworthiness of Male and Female Reporters

\begin{tabular}{|l|c|c|}
\hline Sports & Female Reporters & Male Reporters \\
\hline Football** & 4.25 & 4.68 \\
\hline Baseball** & 4.31 & 4.69 \\
\hline Men's soccer & 4.41 & 4.65 \\
\hline Women's soccer** & 4.65 & 4.34 \\
\hline Men's basketball** & 4.39 & 4.68 \\
\hline Women's basketball** & 4.61 & 4.34 \\
\hline Men's tennis** & 4.45 & 4.60 \\
\hline Women's tennis** & 4.63 & 4.31 \\
\hline Softball** & 4.62 & 4.30 \\
\hline
\end{tabular}

$* * p<.01$

\section{Discussion, Conclusions and Recommendations}

Overall, the participants' knowledge on Title IX was rated in the lower end of the scale (2.77 below the neutral point of 3.0 in Table 1 Statement 9). This seems to reflect that the college students surveyed are not familiar with the gender equality amendment. Statistically, this score indicated $25 \%$ of participants do not have any knowledge of Title IX, and only $31 \%$ have some knowledge about it. The current younger generation seems to be less familiar with this legislation, as only three in five women know the significance of Title IX (Clifton, 2012). This makes the authors wonder if the demographic pays attention to the existing gender-inequity issues in our society in general. The enactment of Title IX was a significant, groundbreaking moment for women because it gave females a voice, both on and off the field. Although Title IX has made a huge difference by enabling females to obtain higher education, advance in the workplace, and participate in sports, this legislation still has its limitations in breaking societal barriers and conceptions, especially in the realm of sports. For example, it cannot change the spectators' taste to like women's sports as much as men's sports. It certainly cannot inform the public's perceptions about female sports reporters'/journalists' competencies and abilities when they try to secure a career in the male dominant sports industry.

In the business world, we witness more and more female CEOs and senior administrators playing leadership roles shaping billion-dollar enterprises and business, however, they still often run into glass ceilings. This is also true in 
the field of sports media and sports journalism, where women struggle to earn comparable salaries and the respect from the public. Our findings did not reveal that participants used undermining languages or displayed blunt mistrust toward female reporters/journalists. However, it is evident that female reporters/journalists are more likely to be judged by their appearance and attractiveness. Although the participants have recognized that female reporters are professional and informative in general, certain stereotypically feminine traits such as friendliness and attractiveness are still highly identified in describing female reporters. Participants also acknowledged that female reporters exhibited a great degree of femininity in their appearance. According to previous research (Arnold et al., 2015; Ewinegar, 2013; Lamoureux, 2012; Tanner, 2001), female reporters/journalists were considered to be less knowledgeable, qualified, and professional than their male counterparts. The degree of prejudice is well documented and continues to affect female individuals who wish to enter the field of sports media vividly. Our study showed that participants believed that women reporters should be relegated to women's locker rooms and men reporters to men's locker rooms. This indicated that the participants tended to equally respect concepts of gender appropriateness and personal rights. In practical terms, this prevents women reporters from covering the most lucrative sports events in a timely fashion. It is also perceived that female reporters/journalists should only stick to their own sports while conducting commentary programs or interviews. If this is what the participants and general public really believe, how can female reporters/ journalists thrive and be successful in their careers, since they can only focus on women's sports and events that are far less financially vibrant, are poorly attended, rarely televised and offer fewer employment opportunities?

It is evident that Title IX does not solve the stereotypical perceptions or discriminatory treatment that females face in the world of sports media. There continues to be persistent concerns over the treatment females receive in the sports industry. Although there has been an increase of female participation in sports, it does not seem to be an urgent issue anymore; our meta-analysis shows that the trends and foci were mainly on adequate and appropriate media representation of female sports. The authors argue as much as it is important to minimize the over-glorification of feminine sexuality, it is also vital to address the work-related and psycho-socio prejudices and discrimination in women's sports. This is also the unique contribution that the second component of our study has offered. Unless these conceptions can be corrected, the pervasiveness of sexism, cases of sexual harassment, and objectification practices will continue to prevent female professionals from reaching their full potential in the industry. Stereotyping and sexism also make promoting female sports extremely challenging and ineffective.

To change the societal view about the professionalism and competencies of female sports athletes, professional, and reporters/journalists, there is a need to further enhance awareness of Title IX, women's rights, and the essence of gender equality. Inappropriate representation of female athletes or reporters may result in their low self-esteem and mental health issues such as anxiety, 
bulimia, and anorexia. There are foundations that are dedicated to promoting female sports and raising awareness of gender equality. One of those foundations is the Women's Sports Foundation, which raises awareness for those seeking to be reporters. This is an organization that educational institutions can collaborate with to bring educational programs to promote gender equality, reduce gender discrimination, and empower females in their professional and athletic roles.

Two specific past studies addressed the issue of popularity of women's sports. Among the five studied themes, perception of women sports reporters was the one emphasized least (along with work-related issues). Perhaps, there is something that can be done to ensure that broadcasting companies televise women's sports programs more frequently. It would take a really long time to cultivate a generation of fans to enjoy female sports as much as the traditional big four male-dominant sports (football, basketball, baseball and hockey). The authors believe educating everyone in understanding diversity and gender equality is the basic step to eliminate our gender prejudicial cultural practices. The participants did have some positive perceptions. First, female reporters' appearance does not have any effect on viewers' trust toward their reporting and professionalism. A significant majority of people still believe female reporters are informative and professional. They are certainly capable of commenting and reporting men's sports, such as football. The perception of male reporters being more knowledgeable and professional on their job is just amale chauvinist idea. There is no doubt female reporters can be just as talented and competent as male reporters.

\section{Recommendations for Future Research and Limitations}

Due to the limited size and geographic region of this study sample, the reader should be cautious in generalizing these findings regarding public opinion of female sports reporters/journalists. An expansion of a bigger sample size and surveys in various geographical regions of the country will be beneficial to gather accurate perceptions on how the general public views the female sports reporters and other professionals. The authors also urge a good balanced amount of studies be conducted in each of the five studied themes. All of these studies will help our society develop a deeper perspective in appreciating female sports and respecting the female sports professionals. Furthermore, it would be ideal if future researchers can conduct studies by involving current female professionals in the field of sports media. They can express the challenges and concerns regarding entering or working in that industry and advise future female apprentices with adequate preparations and mindset for the job.

This study provided some great insights concerning the young peoples' perceptions on professionalism and competencies of female reporters/journalists along with perceived prejudices associated with female professionals. There are some additional limitations that the authors would like to further address. In addition to the small sample size, the study lacks the first-hand knowledge of 
the struggles and challenges faced by female sports reporters. It could be a challenge to actually interview current female sports reporters for any qualitative or quantitative information on the studied issues. With that being said, the primary author got a chance to doa one-on-one interview with Dorian Craft, a female sports reporter for WHAG in Hagerstown, Maryland. This interview helped the primary author shape the research interest and idea for the study. Female reporters, like Lisa Olson, Melissa Ludtke, and Michele Himmelberg have inspired many female journalists to take a stand and fight for gender inequality in sports media. There should be more discussion and research on this topic in order to champion and cultivate future female sports reporters.

In the online survey, the authors neglected to insert additional demographic items for the participants to fill out. Thus, the comparisons on various perceptions and statements based on genders (male respondents' answers vs. female respondents' answers) cannot be performed. Lastly, due to the enormous amount of bibliography available for the meta-analysis, the authors only chose two databases (Google Scholars and EbscoHost) to conduct the search. This decision makes obtaining the full-length articles easier through the library of authors' institution.

\section{References}

Arnold T, Chen S, and Hey W (2015) The rise of women sportscasters: A struggle from sideline to the centerfield. Missouri Journal of Health, Physical Education, Recreation, and Dance 25:36-43.

Burnham A (n.d.) Why Is Women's Sport Treated As a Sideshow? Available at http:// www.independent.co.uk/sport/cricket/andy--burnham-why-is-womens-sport-trea ted-as-a-sideshow-1651726.html

Carlson J (2010) Female Reporters in Male Sports World. Available at http://www. cnn.com/2010/OPINION/09/14/carlson.female.reporter/index.html

Clifton A (2012) The History of Women Sportscasters \& Their Struggle for Equality. Available at http://utdr.utoledo.edu/cgi/viewcontent.cgi?article $=1310 \&$ context $=$ theses-dissertations

Daulton J (2013) The Evolution of Gender Equality in Intercollegiate Sports. Available at http://skyline.bigskyconf.com/cgi/viewcontent.cgi?article=1006 \& context=journal

Ewinegar (2013) The Statistics Behind Media Coverage and Female Athletes. Available at http://tptmn.org/2013/11/26/the-statistics-behind-media-coverage-and-female-ath letes/

Ezzell MB (2009) "'Barbie dolls' on the pitch: Identity work, defensive othering, and inequality in women's rugby". Social Problems 56(1): 111-131. doi:10.1525/sp. 2009.56.1.111

Fink JS (2015) Female athletes, women's sport, and the sport media commercial complex: Have we really “come a long way, baby"? Sport Management Review 18(3): 331342. 
Jacobs P, Schain L (2009) Professional women: The continuing struggle for acceptance and equality. Journal of Academic and Business Ethics Available at http://digital commons.sacredheart.edu/cgi/viewcontent.cgi?article $=1000 \&$ context $=$ cj_fac

Khomutova A, Channon A (2015) Legends' in 'lingerie': Sexuality and athleticism in the 2013 Legends Football League US season. Sociology of Sport Journal 32(2): 161-182. doi:10.1123/ssj.2014-0054

Kian MT, Mondello M, and Vincent J (2009) ESPN—The women's sports network? A content analysis of internet coverage of March Madness. Journal of Broadcasting \& Electronic Media 52(3): 477-495.

Kroh K (2015) Sports Center's Shameful Coverage of Women's Sports. Available at http:// thinkprogress.org/sports/2015/06/12/3668472/media-ignores-womens-sports/

Leeds MA, Von Allmen P (2014) The Economics of Sports (5th ed.). Upper Saddle River, NJ: Pearson.

Lamoureux A (2012) How the Media Portrays Female Athletes. Available at https://ai meelamoureux.wordpress.com/

Lopiano DA (2008) Media Coverage Women's Sports. Available at http://www.sports managementresources.com/library/media-coverage-womens-sports

Mean LJ, Kassing JW (2008) "I would just like to be known as an athlete": Managing hegemony, femininity, and heterosexuality in female sport. Western Journal of Communication 72(2): 126-144. DOI:10.1080/10570310802038564

Mutz M, Meier HE (2014) Successful, sexy, popular: Athletic performance and physical attractiveness as determinants of public interest in male and female soccer players. International Review for the Sociology of Sport 51(5): 1-14. DOI:10.1007/s12662012-0239-7

Rand M (2008) Erin Andrews: "my overall reaction is that it is really sad". Available at http://blogs2.startribune.com/blogs/randball/2008/08/02/erin-andrews-my-ove rall-reaction-is-that-its-really-sad/

Rayburn B, Chen S, and Phillips C(2015) Female college athletes' perceptions on gender stereotypes and discrimination in collegiate athletics. International Journal of Business and Social Sciences 6(5): 28-36.

Sage G, Eitzen S (2013) Sociology of North American Sport (9th ed.). New York: Oxford University Press.

Senne J (2016) Examination of gender equity and female participation in sport. The Sport Journal Available athttp://thesportjournal.org/article/examination-ofgender-equity-and-female-participation-in-sport/

Sherry E, Osborne A, and Nicholson M (2016) Images of sports women: A review. Sex Role 74(7): 299-309.

Shipley A (1999) Medals, celebrity and windfall for U.S. women. Available at http://ww w.washingtonpost.com/wpsrv/sports/soccer/longterm/worldcup99/articles/cup12.htm

Smith LR (2015) What's the best exposure? Examining media representations of female athletes and the impact on collegiate athletes' Self-objectification. Communication \& Sport 4(3): 282-302. DOI: 10.1177/2167479515577080

Tanner J (2001) Women in sports: can they reach parity with men? CQ Researcher 11(18): Available at http://library.cqpress.com/cqresearcher/document.php?id $=$ cqresrre2001051100

Torres P (2016) Attempting to even out the playing field. The Panther. Available at $\mathrm{http} / / / \mathrm{www}$.thepantheronline.com/a-e/attempting-even-playing-field

Women's Sports Foundation (2015) "Pay inequality in athletics". Women's Sports Foundation. Available at https://www.womenssportsfoundation.org/home/resea $\mathrm{rch} /$ articles-and-reports/equity-issues/pay-inequity

Woods R (2011) Social issues in sports. (2nd ed.). Champaign, Illinois: Human Kinetic. 
